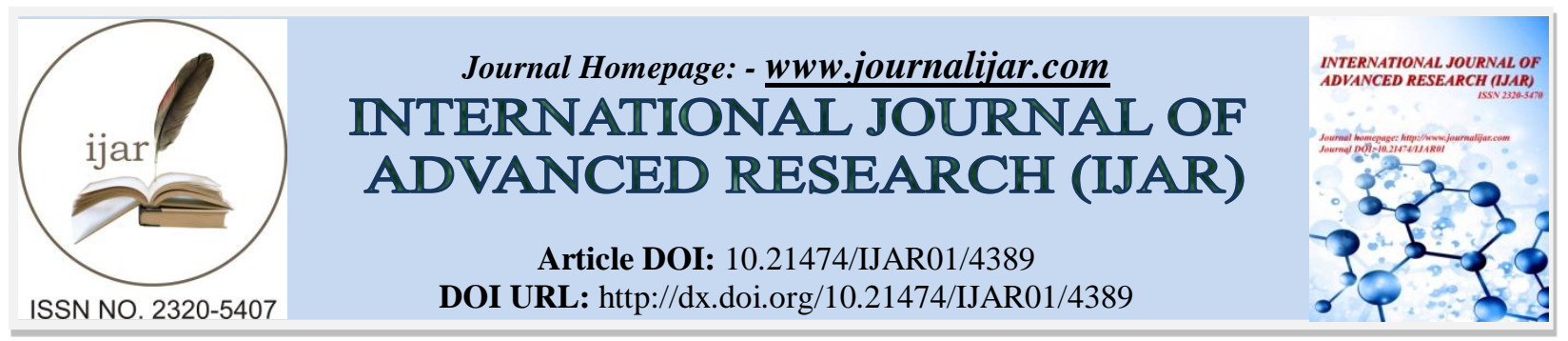

RESEARCH ARTICLE

\title{
MEDIATION OF INFORMATION. SOCIAL NETWORK ANALYSIS IN THE EPISTOLARY COLLECTION OF JORGE DE SENA AND MÉCIA.
}

Maria Otília Pereira Lage.

Integrated Researcher at CITCEM, University of Porto.

\section{Manuscript Info}

\section{Manuscript History}

Received: 03 april 2017

Final Accepted: 05 june 2017

Published: june 2017

Key words:-

Social Networks, Epistolography and

Portuguese Culture; Practices of reading /

writing and Genres / textual / virtual;

Correspondence of Jorge de Sena and Mécia

de Sena; Mediation of Information.

\section{Abstract}

Today's social reality forces us to be able to interact with various forms of socialization, old and new, such as the internet and new social networks, interactive communication platforms and using multiple reading / writing practices in associated textual, digital and virtual genres To various technologies and functionalities coexisting in our technological, literate, technological and network societies. As a reference to such background dynamics, this text presents an exploratory case study of information transfer in contemporary epistolary writing networks, in which the sociocultural perspective of Information is sought to be cross-referenced with the application of the Sociological Analysis of Social Networks Actor-Network) and the principle of "dynamic use" of the network concept (L. Pineau, 1994: 24). In this conceptual and methodological framework, the study focuses on the epistolary collection of Jorge de Sena and Mécia de Sena (Portugal, Brazil, USA, 1940-70) outstanding figures of Portuguese literature and culture, aiming to understand the use of communication and information And the application of local-global knowledge in intellectual communities. Following the social actors, typologies and elements of "social networks" are observed in this epistolary dialogue that feeds and redefines action and knowledge, academic work and research, literary creation and intercultural relations, means of illustration of information mediation to its sociocultural dimension. It concludes by the importance of the approximation of Information Science to the Social Studies of Sciences and Technologies that allow to understand social processes and technological innovation, and relevance of this approach in the skills of the information manager in the 21 st century.

Copy Right, IJAR, 2017,. All rights reserved.

\section{Introduction:-}

As an exercise oriented towards a reflexion regarding cognitive aptitudes and inter/intrapersonal attitudes at the intersection between culture, communication and creativity, this text is underlined by a "located knowledge" ${ }^{1}$ in

\footnotetext{
${ }^{1}$ Donna Haraway e Sandra Harding, renowned American authors on scientific and social women's
} studies. See for example SANTOS, Maria Cecília MacDowell dos (1995) - Quem pode falar, onde e 
which two personal passions protrude: that of documentation and information sciences and that of historical, social, and cultural studies. It was our malleable and resistant ambition to meet the current relevance of historical and methodological studies of socio-cultural objects and phenomena which involve the production, management and mediation of information and knowledge in different domains.

One begins with the assumption that identical positions can present an interesting challenge for future information managers, who we consider to be communicators of "collective values", "moulders and defenders" of cultures (Heskett \&Schlesinger, 1996:130), necessarily endowed with vast intellectual and cultural capital, seen as culture nowadays is an important asset in any organisation, but also with a new attitude, that of passion for knowledge and for the wisdom that will equip them to deal with their emotions, to interpret stimuli and successfully aggregate intelligent collectives in competitive environments. The somewhat excessive challenge which we therefore embrace, with conviction and an indeclinable sense of duty, in information, historical, cultural and citizenship frameworks, naturally entails obstacles which are difficult to overcome, but also the potentiality for development of other studies in various domains of Documentation, Information, and Communication Sciences, of Cultural and Literary Studies and of Social and Cultural History on a vast scope which we here aim to outline.

The current text focuses on a study which echoes some of our previous work regarding the life and work of Jorge de Sena and Mécia de Sena (2005-2016) ${ }^{2}$ and which now revolves around the theme of "Social Networks and Correspondence" drawing on the intensive analysis of the documental collection produced by the epistolary dialogue between this great writer and his wife, distinguished figures within Portuguese literature and culture $\left(20^{\text {th }}\right.$ century). It consists in an autobiographical area of high sensitivity and human and socio-cultural magnitude of renowned public and academic interest, in which, given its documental, historical-cultural and literary history, an enormous communicative and informative potential is evidenced. This case study, undertaken in the light of the Sociological Analysis of Social Networks ${ }^{3}$ and, in particular, of Actor Network Theory (ANT/TNA) ${ }^{4}$, started being motivated by some of this correspondence's dominant social characteristics and by the mediated influence of the increasing impact of the New Social Networks of Cyberspace, eventually laying the foundations for a confluence of informational competences inherent to the preservation, organisation, publicizing and mediation of information ${ }^{5}$ of the considerable documentation on which is grounded the tutelary figure of Mécia de Sena, a tireless archivist, organiser, studious and dynamic of the complete edition of the consecrated Senian works.

\section{Social networks and Correspondence:-}

The comprehensive and current theme through which we move is anchored, initially, on the vast domain of reading and writing, in its broadest sense, which enables the encompassment of social and cultural participation. It therefore detains a privileged status in our technological and literate societies. These help us to, but also demand us to, read and write well, make our thoughts heard, develop and communicate ideas, live and coexist with dignity and, in the

como? Uma conversa "não inocente" com Donna Haraway. "Revista Critica de Ciências Sociais", Coimbra, $\mathrm{N}^{\circ} 44$ December. 1995

2 Among other texts, there stand out of other texts, communications and articles, the following works of our own authorship since published: LAGE (2007 )- Correspondência(S) Mécia/Jorge de Sena (Uma Evocação de Carrazeda, anos 1940). Guimarães: NEPS-U.Minho; LAGE (2010) - Portugal como (Im)Possibilidade Continuada: Cidadania e Exílios (1930-1970). À «Conversa» com Jorge de Sena.Porto: Ediçoes Afrontamento; LAGE, Org. (2013) - Correspondência. Jorge de Sena e Mécia de Sena «Vita Nuova» (Brasil, 1959-1965). Porto: CITCEM; Edições Afrontamento; LAGE (2016) - Mécia de Sena e a escrita epistolar com Jorge de Sena. Porto: CITCEM; Edições Afrontamento.

${ }^{3}$ PORTUGAL, Sílvia (2007) - Contributos para uma discussão do conceito de rede na teoria sociológica. Oficina do CES, Coimbra, Mar. Available at http://www.ces.uc.pt/publicacoes/oficina/271/271.pdf [ accessed on 24 Sept.2016]; IMÍZCOZ BEUNZA, José María, ARROYO RUIZ, Lara - (2011) Redes sociales y correspondencia epistolar. Del análisis cualitativo de las relaciones personales a la reconstrucción de redes egocentradas. "REDES- Revista hispana para el análisis de redes sociales" Vol. 21, n⿳⺈, Diciembre.

4 LATOUR, Bruno, (2005)- Reassembling the Social: An introduction to Actor-Network-Theory. Oxford: Oxford University Press.

${ }^{5}$ VALENTIM, Marta, Org. (2010)- Gestão, mediação e uso da informação [online]. São Paulo: Editora UNESP; São Paulo: Cultura Acadêmica, ISBN 978-85-7983-117-1. Available at SciELO Books .http://static.scielo.org/scielobooks/j4gkh/pdf/valentim-9788579831171.pdf [ Acessed on 3 Mar. 2017] 
most diverse instances of our daily lives, to access information to defend our points of view and to share legitimate cultural goods, thus being able exercise a full citizenship.

The socio-cultural realities of the society of information and knowledge force us to be able to interact with the most recent forms of socialisation, such as for example the internet and the new social networks. The possibilities for communicating with one another have grown exponentially and we are nowadays able to engage in multiple reading and writing practices through a diversity of textual and virtual genres, which implies skills and aptitudes in different modalities of use, management and mediation of information.

\section{Reading/writing practices and textual/virtual Genres:-}

The oldest textual genres, such as letters (personal, private, public, institutional or of a different nature), or notes or memoranda arose and developed with the emergence of writing. In the same fashion, from telephones and cellular phones which support written and oral texts, arose virtual genres, such as the phone call, the cell phone, the text or short text messages which remain textual genres. In a similar way, the computer and the internet allowed for the composition of new genres, such as the e-mail, the blog, the chat, among others, which can be textual and virtual genres. More recently, the appearance of social networks (Orkut, Facebook, Twitter, MySpace) enabled internet users to experience the most diverse relations beyond their local communities. Their main characteristic is the interactivity in real time which cancels out space and compresses time, when compared to conventional letters, older forms of communication.

It is important, however, to highlight the fact that not always does the emergence of a new technology favour the creation of a new textual genre; and that the new textual genres are built upon older foundations. We can as such observe that the letter is a textual genre similar to a conversation, and that in turn the e-mail refers to the composition of a letter. Consequently, all these transformations coexist with older inputs in our contemporaneity, resulting therefore in the need for both to be incorporated in current reading and writing practices, as they are tools, albeit with different functions, which are equally useful in our daily lives.

Let us emphasise, for instance, some contact points that remain between older communication tools and newer ones on the internet, such as personal and private correspondence or electronic mail, email and Facebook, new social network ${ }^{6}$ : both are means of sharing and collaboration (they share information and influence the like which they keep constantly and socially up to date); upon both looms the considered risk of ultra-mediatisation of privacy and intimacy $^{7}$; they allow for a dialogical discourse analysis (M Baktin) as enunciation, live discourse, objective and interactive; both demand a use and management of information in a processual fashion (these steps being connected horizontally and vertically), logically and dialectically, in a comprehensive, integrative and specific way and with both rigor and flexibility.

\section{Mediating Information:-}

Mediation emphasises the social character of information, that the latter does not exist outside of society and culture, demonstrating the singularities of the informational issue, of the conditions of production and appropriation of information. The progressive use of this concept in successive information mediation studies has come to demonstrate that knowledge and meaning are not mere data, being conversely always a by-product of elaboration (JEANNERET, 2009, p. 26), which allows one to underline the circumstance of, in culture, symbolic forms, actors and roles, not being able to deal with what appears to be "right" or "transparent". We must, then, upon mediation studies, act with caution regarding immediate approaches to the facts, and instead, bring to the table the different actors, proceedings and devices involved in a symbolic and practical dimension of culture. It is common to conceptualise mediation as a type of practice or action, that is, the notion of acting as intermediary: "[...] the role of

\footnotetext{
${ }^{6}$ SEARA, Isabel Roboredo - Da epístola à mensagem electrónica. Metamorfoses das rotinas verbais. Lisboa: Universidade Aberta, 2006. Ver também RIBEIRO, Camila Belizário (2015) - Géneros discursivos e atos de fala no facebook: uma análise de posts e memes relacionados às eleições para a presidência do brasil em 2014 (tese de mestrado em linguística).Lisboa: Universidade de Lisboa-Faculdade de Letras. Available at http://repositorio.ul.pt/bitstream/10451/25626/1/ulf1212799_tm.pdf [ accessed on 12 February 2017]

${ }^{7}$ Facebook is already testing encrypted messages. The chat service of the social network presided by Mark Zuckerberg wants to strengthen security in private conversations on the service and is already testing solutions like the one already in use on the international communication network WhatsApp."Jornal de Negócios", Jul. 2016. - Tecnologias/ Alexandra Noronha.
} 
intermediary facilitating communication is meant to favour the transition to a better state" (DAVALLON, 2007, p. 06). This understanding is present in Information and Communication Sciences when they present mediation proceedings in the organisations and professional activity of every domain. This dimension can be found in information mediation studies, as a practice and a process which encompasses the interference actions regarding information, which can range from direct and conscious actions, even indirect and unconscious, individual or collective, singular or plural, which bring about the appropriation of information.

The concept of Mediation, essential to a more complex and extensive comprehension of information, features three notions: appropriation, reception and interference. What is meant by appropriation are the processes of daily life and their surrounding contextualization which suppose the understanding and decoding of messages; as for reception, which has been approached by Cultural Studies (Stuart Hall, 1980), one must take into account the message coding/decoding processual model put forward by S. Hall with the aim of understanding the hegemonic power of means of information in social and ideological processes; in turn, the notion of interference denotes that the appropriation of information depends on the readers and reading practices which mediate the construction of knowledge.

In this light, what is understood by information is rendered more complex but also clearer, in that it can be said that it is neither contained in the object nor the subject but rather in the mediation which is established between both, while "...the mediation of information is a historical-social process and results from the connection of the subjects with the world" (ALMEIDA JUNIOR, 2009, p. 93), as historical beings. Therefore, information must be perceived as not merely transmitted, but instead embedded in the knowledge which it helps in transforming. In order to be appropriated, information depends on reading, readers and their practices which mediate the construction of knowledge. Information is never simply transmitted, as the means of information are parts of information and reading practices which seek to make communication in society possible, it being a place in which meanings are constructed or transformed. Thus, mediation is an research resource in Information and Communication Science which allows us to analyse informational objects which are simultaneously technical, social and signifying devices (DAVALLON, 2007)..

\section{Study Of The Jorge De Sena/ Mécia De Sena Correspondence And Social Networks:-}

Drawing on the previously expounded general understanding, we understand that the approximation between Information Science, in its transdisciplinary dimension, and Social Studies of Science and Technology can significantly contribute to a greater potentialisation and consolidation of new information studies under the sociocultural perspective we have defended and which underlays as base dynamic the case study here briefly presented.

Testifying that this innovative and promising sociological analysis of social networks, partly influenced at its initial development, among others, by Information and Technology Sciences, exerts today also its own impact and influence, in the field of Information Science, notably through the theoretical and methodological contribution of Bruno Latour in the scientific production of this field, by means of the multiple analytical possibilities which it provides ${ }^{9}$, we sought to combine procedures from these two fields in our conceptual and methodological approach in the case study we here only outline, in which we adopt the conception inherent to the social studies of science and technology that knowledge and science are a social and historical construction and must be understood as such.

\footnotetext{
${ }^{8}$ Apud VAlENTIM, Marta, Org. (2010) - Gestão, mediação e uso da informação [online]. São Paulo: Editora UNESP; São Paulo: Cultura Acadêmica. Disponivel em SciELO Books http://static.scielo.org/scielobooks/j4gkh/pdf/valentim-9788579831171.pdf [ acessed on 3 Mar. 2017]

9 According to citation studies in periodical articles, Bruno Latour's most referenced works in Information Science works in Brazil are: Ciência em acção (2000), Redes que a razão desconhece (2000), Jamais . fomos modernos (1994) and Vida de laboratório (1997). ARAUJO, Ronaldo Ferreira, FROTA, Maria Guiomar da Cunha, CARDOSO, Ana Maria Pereira - Práticas, inscrições e redes sociotécnicas: contribuições de Bruno Latour e dos Estudos Sociais da Ciência e da Tecnologia para a Ciência da Informação. Available at https://digitalisdsp.uc.pt/jspui/bitstream/10316.2/31889/1/10-

$\% 20 \mathrm{a} \% 20$ ci\%C3\%AAncia\%20da\%20informa\%C3\%A7\%C3\%A3o\%20criadora\%20de\%20conhecimento\%20vol\% 20II.pdf?ln=pt-pt [Accessed on 5 Mar. 2017].
} 


\section{Theoretical And Methodological Framework:-}

The conceptual-methodological approach deployed for this study of the correspondence between Jorge de Sena and Mecia de Sena in the scope of the vast and varied social networks which this couple interweaved with several social actors is inspired by the so called 'Teoria do Actor Rede' (TAR) or 'Actor-Network Theory' (ANT) which allows us to understand the technological innovation processes and, in particular, the version of the social actors as 'agents' or 'network' proposed in various studies, among others, from the anthropologist and science and technology sociologist Bruno Latour. Throughout the 1990s, we witnessed the expansion and consolidation of the actor-network theory which had begun to take shape in the previous decade and which hasn't stopped evolving since, despite the polemics and controversies it brought about from more conventional approaches.

More than a theory, TAR/ANT is a set of approaches which share common premises and procedures. The version that is followed here is specifically suited for the task of tracing the constitutional processes of strong associations between social actors (human and non-human) which allow to 'make exist' multiple entities which can be known and manipulated in the research practice framework.

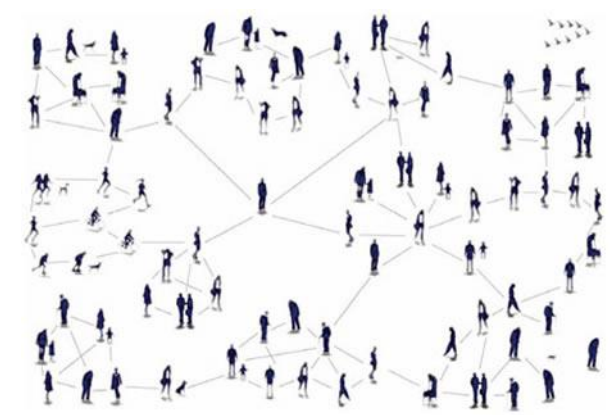

Fig. 1:- Social Networks - "Actor-Network Theory “10

The epistolary writing we tackle constitutes an exemplary case of the kind of social processes described and debated in the scope of TAN/ANT which its own vocabulary which includes, among others, analytical devices, notions and moments of analysis which we aim to apply as : 1- 'translation' (problematisation, listing, application...), a process through which certain actors become indispensable to respond to a given situation or problem, compelling other actors to join those who problematized; 2- 'following the actors' through new problematisation which involves the establishing of a mandatory "transaction area" for all actors, without which they will not be able to respond adequate and successfully to the situation (in accordance with their expectations and objectives); 3 - 'mobilisation', which refers to the way in which the 'problematisers' become spokesmen for other actors who were 'interested' and 'enlisted'.

In situations like those who were here revealed as necessary to take into consideration, the expected results at the level of knowledge are obtained through the establishment of outlines which presume to be more accurate and meticulous, as well as the means to test them so as to test their ability to resist critiques or alternative problematisations.

We thus verify that, as a methodological resource ANT enables one to pinpoint the collective aspect of the construction and transference of knowledge and its stabilisation process. [While] the theoretical potential of the ANT allows one to identify and trace the actors, networks, intermediation and movements in the articulations that involve the production, circulation and use of registered information and of documents. . ${ }^{11}$

The material used in the documental analysis of this concrete 'epistolary dialogue' (in the light of documentation and information sciences and proposals from the "sociology of associations" (Bruno Latour et al.), were hundreds of

\footnotetext{
${ }^{10}$ Fonte : Bienes Comunes Sociales, Sursiendo hilos sueltos (Oct.15, 2013) Available at https://sursiendo.com/blog/2013/10/la-propuesta-de-bruno-latour-y-la-teoria-del-actor-red/ [ Accessed on 2 May 2017]

${ }^{11}$ ARAUJO, R. F., FROTA, M.G.da C., CARDOSO, A. M.P., Ob cit.
} 
published letters from Jorge and Mécia de Sena ${ }^{12}$ and in particular the series of over 100 Letters from Exile (Brazil, 1959-1965), fully edited ${ }^{13}$, paying special attention to the identification and tracing of the countless constant references in the documental and literary narratives of the two correspondents to multiple protagonists and groups of national and international public figures with whom the couple were interrelated and which constitute a vast ramification of social networks which are seen throughout the correspondence.

Our focus will then be, in the section that follows, on the analytical description and demonstration of this case study centred around the correspondence of the Sena couple and their close relationship with an array of networks which run through these writing networks: 'egocentered networks', 'intimate networks', intellectuals and political exiles' networks, networks of public figures and social groups from diverse fields and backgrounds (arts and letters, press, politics, science and academics, journalism, etc.)

\section{The Analysis:-}

The correspondence of the Sena married couple (critical intellectuals and authors of broad epistolary writing) constitutes an exceptional case of Portuguese culture and epistolography: It is simultaneously layered with constant inter-personal relations, of family, of friendship and of hospitality, extensive and varied writing, social, intellectual and intercultural networks with multiple interconnections interwoven and identifiable throughout its intense and lengthy epistolary dialogue.

This epistolary collection consists of thousands of letters from the Sena couple, a historical "loving couple" of Portuguese literature, written in a private life and social domain, in connection with multiple and diverse social networks, a collection which was produced over a broad spacio-temporal frame: Portugal-Brazil-USA-Europe, 1940s - 1970s. The noteworthy assiduity and profound relationship which can be seen throughout the letters of both correspondents, whilst always attentive to the 'me/other(s)' dynamic and everything in their surroundings, allows one to see this correspondence as if a diary written by four hands and a "monument to daily love" (Vasco Graça Moura, 2014 $)^{14}$. As a means of direct interaction, in a close and rich personal and social interrelation, and of intense communication between two distinguished figures if Portuguese literature and culture, exceptional human beings, this lasting and steady correspondence is globally characterised by a pluridimensionality between: public/private, love/daily life, personal/social, documental/literary, routine/creativity, and by an epistolary writing in which one witnesses the suspension of biographical certainty.

They are letters of daily frequency, filled with a non-transcendental love, instead of great tenderness, complicity and eroticism in an always open search of the 'me', the 'you', and the essential 'other', in personal and social plenitude which bring out the contemporaneity of their writings' historical moments in a lively documental and literary expression. As letters which both are and make history, in their commented register of historical-social events and realities in Portugal and throughout the World across which the interlocutors shared their lives, constitute still a significative repository of multiple social networks interwoven by the married couple in constant awareness of the 'other(s)'.

We must also highlight its visible literary value in many evidences of the epistolary writing of both correspondents, in frequent echoes of Jorge's poetry, in the constant references to the Senian oeuvre, in the frequent dispatch of the poems of Jorge Sena and other poets, in details of lucid introspection and discursive rhetoric. The literary dimension intersects with the socio-historical perspective, the personal intersects with the social, the more intimist reasoning validates the perspective on the 'other' (singular or collective), the amorous complicity intersects with the disenfranchisement with the country. All this in a register which only the letter, as a "space of freedom and polemic", allows for, due to the fact that it "generates an interaction dialogic space, in which the writing subject

\footnotetext{
${ }^{12}$ Notably in the following works: SENA, Mécia de, Compil, Org., Coord. (1982) - Isto Tudo que nos rodeia (Cartas de Amor). Lisboa: Imprensa Nacional-Casa da Moeda. (Col. Autores Portugueses); LAGE, Maria Otilia Pereira Lage, Org. (2013)- Correspondência: Jorge de Sena e Mécia de Sena "Vita Nuova" (Brasil, 1959-1965).Porto: CITCEM/Afrontamento; LAGE, Maria Otilia Pereira Lage (2016) Mécia de Sena e a escrita epistolar com Jorge de Sena: Para a História da cultura portuguesa contemporânea. Edição CITCEM /Afrontamento.

${ }_{14}^{13}$ LAGE, Coord. (2013) - Ob cit.

${ }^{14}$ Vasco Graça Moura - Critical review of the book LAGE, Org. (2013) - Correspondência brasileira entre Jorge de Sena e Mécia de Sena (1959-1965): Vita Nuova . Ed. Porto: Citcem/Afrontamento, In "Expresso Online, Abril 2014
} 
passes a torch, sends messages, trying to act directly on the opinion and cognizance of his interlocutor" (LAGE, 2016: 91$)^{15}$

Thus, and in addition to the clear historical and documental interest in these 'foundational' letters, this correspondence can also be considered a 'machinic' device of Senian opus production. ${ }^{16}$

\section{Cycles and Series of this Epistolary Writing:-}

This correspondence's sociologically informed documental analysis, which Mécia de Sena meticulously preserved and organised/catalogued, also allowed us to consider that its production developed in three space-time cycles to which, respectively, three different series correspond: a $1^{\text {st }}$ cycle, Portugal in the 1940s-50s (Motherland Cycle) to which correspond the first letters of mutual insight, friendship, falling in love and love which constitute the first series - "Letters of love and falling in love: two accompanied solitudes", partially published ${ }^{17}$; a $2^{\text {nd }}$ Cycle, "Vita Nuova" (Cycle of the Brazilian exile, 1959-1965) to which corresponds the $2^{\text {nd }}$ series - Camilian-flavoured letters [according to Mécia], or happiness writing [according to Jorge], the only one fully edited and studies as a set ${ }^{18} ; 3^{\text {rd }}$ and last cycle relating to the correspondence from the United States, 1968-1975 (American cycle), which includes the $3^{\text {rd }}$ Series of letters, authentic live reportages of vivid and striking events of the western world's contemporary history, to which we attribute, on the basis of the physical and psychological context of his writing in "Under the sign of the voyage", the 'me' and the 'other'. The production of the couple's epistolary writing notes around 500 letters in this period, besides illustrated postcards, telegrams and notes from some of their 9 children. Only a small fraction has been published $^{19}$. However, what we know of it allows us to see, in the richness of its heterogeneity, which, with regards to what refers to Europe, with the account of Jorge de Sena's travels which pepper this period's letters, a transition from the "optimism, enthusiasm, discovery" salient between 1968-69 to the "slow and painful ebbing away of utopias and dreams", and from the "initial commotion of the restauration of democracy and freedom in Portugal in the post $25^{\text {th }}$ of April period, followed shortly by the profound disenchantment and discouragement".

\section{Reconstitution of Social Networks (typologies and elements)}

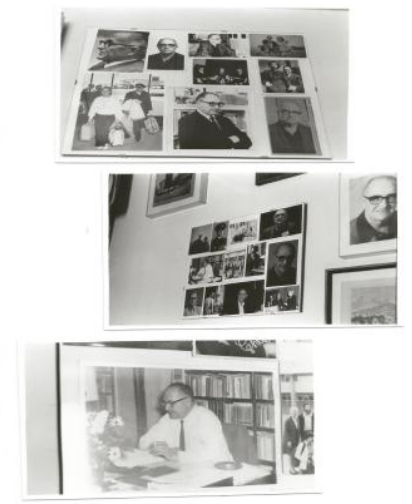

Fig. 2:- Moments and environments of Jorge de Sena and Mécia.

\footnotetext{
${ }^{15}$ LAGE, Maria Otilia Pereira (2016) - Ob cit.

16 DELEUZE, Gilles, Félix, GUATTARI (2003) - Kafka-Por uma literatura menor. Lisboa: Assírio \& Alvim,

${ }^{17}$ LAGE; Maria Otilia Pereira, Org. (2013) - Correspondência Jorge Sena e Mécia de Sena (Brasil, 1959-1965): “Vita Nuova”.Porto: CITCEM/ Afrontamento.

18 SENA, Mécia de, Compil, Org., Coord. (1982) - Mécia de Sena, Jorge de Sena. Isto Tudo que nos rodeia ( Cartas de Amor). Lisboa: Imprensa Nacional / Casa da Moeda. (Col. Autores Portugueses). The knowledge of this inaugural anthology of the publication of this Correspondence influenced the publishing of more scattered letters from this $1^{\text {st }}$ series, some of which about Carrazeda de Ansiães, at our responsibility with the generous permission D.Mécia de Sena.

${ }^{19}$ Of this cycle / series, beside one or other published and analysed letter for example on the Rio de Janeiro website "Ler Jorge de Sena" https://lerjorgedesena.wordpress.com, certain excerpts of Mécia de Sena letters from 1971 published and studied ( $2^{\circ}$ viagem de Jorge de Sena à Europa) in LAGE, Maria Otilia Pereira (2016) - Mécia de Sena e a escrita epistolar com Jorge de Sena. Para a historia da cultura portuguesa contemporânea. Porto: CITCEM/ Afrontamento, pp. 90-167.
} 
In the scope of the Sociological Analysis of Social Networks we can identify and reconstruct the correspondence of Jorge and Mécia de Sena, a branching of various symmetrical social networks which are defined through 'nots', active and passive ties, 'resource channels', 'structural relations', connections between social system and actors. These 'associative' and 'egocentered' networks can distinguish themselves in their elements and typologies, by reference to the production cycles/series of this private epistolary: $1^{\text {st }}$ Cycle, of the motherland/ Intimate networks (family, personal) and social - friendship, solidarity and conviviality; $2^{\text {nd }}$ Cycle, exile and Luso-Brazilian dialogue/Writing and empowerment social networks - over a hundred actors and social groups (editors, professors, writers, intellectual, political exiles...) distinguished in multi sectors :journalism, higher education, arts and letters, literature, politics; $3^{\text {rd }}$ Cycle - American exile and trips to Europe./ Hospitality, research, literature and culture collaborative social networks.

To summarise, this approach reveals itself a referential information element for whoever wishes to challenge this epistolographic set again or to study new ones. The analytical, conceptual and epistemological framework is a promising hermeneutical tool which will render it possible to add another piece to literary, historical, cultural, sociological or biographical knowledge of these two personalities who laid in what they wrote and bequeathed us (the correspondence exchanged between them is one example) polysemic, (and as such always susceptible of investigative regressions) information and clues.

\section{Final Notes:-}

The study here synthetically presented, a brief essay in the light of social networks, a concept of growing predominance in social practice and a lot of areas of knowledge, whose importance we sought to highlight as an researcher resource in the scope of relevant and current informational issues, such as the mediation of information, constitutes the main empirical and analytical device of this text. We believe to have demonstrated that to "bring closer Science and Technology Social Studies (founded by Bruno Latour) to Information Science in the possibility for a new research perspective for this field, can significantly contribute to the potentiation and consolidation of information studies from a sociocultural perspective, breaking the distanced and global vision of science, in order to get closer to the - institutionally, socially and culturally - located production spaces" 20

The epistolary 'corpus' here analysed is a constituent part of the Assets of Jorge de Sena [Lisbon, 1919 - Santa Barbara, 1978] which Mécia de Sena exemplarily preserved, organised and placed, in great intellectual openness, at the disposal of countless researchers throughout the world during successive decades in the writer's family house in Santa Barbara, California, (USA) and which she would end up donating freely to Portugal in 2009, in an exemplary attitude of citizenship and historical, patrimonial and cultural awareness which is only fair to highlight. These assets which reside today in BNP-Reservados, where under certain conditions it may be queried and studies, includes besides other articles and materials, voluminous documentation of varied nature (biographical, epistolary, museological, manuscripts and original versions of Senian literary oeuvres, conferences, lectures and texts of Jorge de Sena published in Portuguese and Brazilian press) in which stands out the very vast and diverse epistolary of the writer, a core in which the familiar is emphasised, with special prominence to the collection of letters exchanged between Jorge and Mécia over the course of thirty years of an intensely shared lifetime.

In this regard it is important to underline the growing importance of private and personal archives - a source domain of undeniable interest, for daily historical research it has become a predominant tendency in American and European history, valuing this new look unto history which focuses on feelings, habits, behaviours and selects a special form of intimate diaries, personal correspondence, notes found in writers', artists', politicians', and other public figures' assets. The publishing and study of this type of sources, alone or in series, has been used by historians to amplify the debating and understanding of themes, characters and epochs drawing on new methodological focuses, new perspectives and renovative historiographical practices.

From this broader context is reclaimed, incidentally, the lengthy study which we have been making of the lifework of Jorge and Mécia de Sena, which we here resume, and refocus it on the intersection of analytical challenges and assumptions of Information Sciences and of Social Networks Sociological Analysis ${ }^{21}$ of growing popularity in current network societies, appealing to recent studies in the field of Information Science, so as to in this way

${ }^{20}$ ARAUJO, R. F., FROTA, M.G.da C., CARDOSO, A. M.P., Ob cit. 
contribute to a broader horizon of opportunities of new and promising studies of interest to information managers of the $21^{\text {st }}$ century.

\section{Bibliographical References:-}

1. ARAÚJO, Ronaldo Ferreira, FROTA, Maria Guiomar da Cunha, CARDOSO, Ana Maria Pereira - Práticas, inscrições e redes sociotécnicas: contribuições de Bruno Latour e dos Estudos Sociais da Ciência e da Tecnologia para a Ciência da Informação. Available at https://digitalisdsp.uc.pt/jspui/bitstream/10316.2/31889/1/10 [Accessed 5 Mar. 2017].

2. DELEUZE, Gilles, Félix, GUATTARI - Kafka-Por uma literatura menor. Lisboa: Assírio \& Alvim,2003.

3. IMÍZCOZ BEUNZA, José María, ARROYO RUIZ, Lara - Redes sociales y correspondencia epistolar. Del análisis cualitativo de las relaciones personales a la reconstrucción de redes egocentradas. "REDES" Vol. 21, nº 4, Diciembre, 2011.

4. LAGE, Maria Otilia Pereira - Mécia de Sena e a escrita epistolar com Jorge de Sena: Para a História da cultura portuguesa contemporânea. Edição CITCEM /Afrontamento, 2016.

5. LAGE, Maria Otilia Pereira Org. - Correspondência. Jorge de Sena e Mécia de Sena «Vita Nuova» (Brasil, 1959-1965). Porto: CITCEM; Ed.Afrontamento, 2013

6. LATOUR, Bruno - Changer la société-refaire de la sociologie. Paris, La Découverte, 2006.

7. LATOUR, Bruno - Reassembling the Social: An introduction to Actor-Network-Theory. Oxford: Oxford University Press, 2005.

8. PORTUGAL, Sílvia - Contributos para uma discussão do conceito de rede na teoria sociológica. "Oficina do CES", n' 271, 2007

9. REDES - Revista hispana para el análisis de redes sociales Vol. 22, 4, Junio, 2012, Vol. $21,4$.

10. SEARA, Isabel Roboredo - Da epístola à mensagem electrónica. Metamorfoses das rotinas verbais. Lisboa: Universidade Aberta, 2006.

11. SENA, Mécia de, Compil, Org., Coord.-Mécia de Sena, Jorge de Sena. Isto Tudo que nos rodeia ( Cartas de Amor). Lisboa: Imprensa Nacional / Casa da Moeda, 1982.

12. VALENTIM, Marta, Org. - Gestão, mediação e uso da informação [online]. São Paulo: Editora UNESP; São Paulo: Cultura Académica, 2010. 